\title{
Plain Concrete の内部摩擦角と引張強度についての一考察 \\ STUDY ON INTERNAL FRICTION ANGLE \\ AND TENSILE STRENGTH \\ OF PLAIN CONCRETE
}

\author{
藤田吉夫*，石丸 麟太郎**，花井重 孝***，末永保 美**** \\ Yoshio FUJITA, Rintaro ISHIMARU, Shigetaka HANAI \\ and Yasuyoshi SUENAGA
}

\begin{abstract}
In general, 37 degrees is applied for internal friction angle value $(\phi)$ of concrete and $8 \sim 10 \%$ value of compressive strength is for tensile strength value of it as well. However the theoretical solution of internal friction angle is calculated as 57.5 degrees by the equivalence that linear elastic theoretical solution of concrete split test is equivalent to wedge theoretical solution of it.

We experimented on partial compression test of plain concrete for making sure of this fact. As a result, it was proved that the test result well equal to wedge theoretical solutions at $\phi=55$ and $\mathrm{Ft}=0.05 \mathrm{Fc}$.
\end{abstract}

KEYWORDS: Internal friction angle, Tensile strength, Wedge theory, Compressive failure, Split test,

Plain concrete

内部摩擦角、引張強度、くさび理論、圧縮すべり破壊、割裂試験

\section{1.はじめに}

筆者等は文献 1 において Plain concrete の支圧強度に関する 「くさび理論」を発表し、その後文献 2 および文献 3 において「く さび理論」の応用として鉄筋コンクリートはり・柱のせん断強度に 関する理論的解析法について述へ、一部は実験値との比較を試みた。 これらの文献中ではコンクリートの内部摩擦角をコンクリートによ く合うとされる $\phi=37^{\circ} 、 \mathrm{Ftt}=\mathrm{Ft} / \mathrm{Fc}=0.1$ の值を用いて結果を遒い てきた。文献 2 において実験値と理論值の比の分布は、一律に 1 . $0 \sim 0.7$ の範囲にあり、理論值の方がやや高めにてていることを 指摘し、この原因はFt $\mathrm{t}=0.1$ としたためと論じた。しかし、その後 の考察によりこの原因として、くさび理論が上界の解であること、 $\phi の$ 值、Fttの值の 3 つが考えられるが、くさび理論に立脚すると、 後述するようにくさび理論と円柱の割裂テストの理論式との間の関 係から、内部摩擦角は $\phi=\tan ^{-1}(\pi / 2)=57.5^{\circ}$ となることが理論的 に導かれる。

この両者の差に着目し、コンクリート（モルタル）のめの值およ び真の引張強度と压縮強度との関係を求めるための実験を行い実験 值の統計解析をすると、くさび理論を用いた場合、 $\phi=55^{\circ} 、 \mathrm{Ftt}=$ $\mathrm{Ft} / \mathrm{Fc}=0.05$ の時に㬰験值と理論值がよく一致するという結果を得た のでその結果について報告する。
また、実験の結果を用い算定した隹縮すべり角度および円柱の割裂 テストに於ける引張強度の圧縮強度に対する見かけの割合等につい てくさび理論を適用した結果について述へることとする。

\section{Plain concrete の压致試験}

\section{1 英壆の概要}

（1）試験体の形状および加力方法

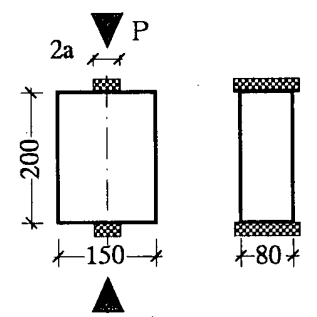

Fig 1 Shape and loading method of a specimen

試験体の形状はFig 1 に示すように $150 \mathrm{H} \times 80 \mathrm{~L} \times 200 \mathrm{H}$ とし、熱処理 材に機械加工をした上下の加力板を介して万能試験機（5t f レン ジを使用）により加力する。加力板のコンクリート側にはグリース を塗布した。

\footnotetext{
* (侑)香建築事務所

** (有)香建築事務所 代表取締役・工博

*** 日本大学生座工学部建築工学科 専任講師・工博

***** 横浜国立大学 名誉教授・工博
}

Kaoru Architect Office

Kaoru Architect Office, Dr. Eng.

Lecturer, Dept. of Architecture Engineering, College of Industrial Technology, Nihon Univ., Dr. Eng.

Emeritus Prof., Yokohama National Univ., Dr. Eng. 
（2）試験体の材質、製作および養生

試験体はロット毎の材料の品質が安定するようプレミックス型の モルタルを選定し、1 ロット15個が製作できる金型を用いて 4 週強 度が $270 \mathrm{kgf} / \mathrm{cm}^{2}$ となるよう水セメント比を定めて製作した後、表面 に湿潤した布をかぶせ着生し、武験日まで央験室に放置した。モル タルの混合主成分は以下の通りであり、混合比は公表されていない。

・普通ポルトランドセメント

- 粒度調整済乾燥砂 $(\mathrm{S} / \mathrm{C}=2 ， 0)$

・セメント系収縮補正材

・化学糊材 (メチルセルローズ系)

・高性能減水剂

・膨張剂

(3) 実験パラメーターおよび武験体数

実験のパラメーターはくさび理論に於ける $\beta$ の值とし、Fig 1 の 2 $\mathrm{a}$ の值を変動させて行う。試験のシリーズ名、 $\beta$ 、 $2 \mathrm{a}$ 、加力面積 $S$ の 值および試験体数をTable 1 に示す。試験体数は $\mathrm{t}$ 分布の変動が少な くなる $\mathrm{n}=38 \sim 40$ とした。また、环縮武験用のテストピースは 1 ロット当たり $100 \phi \times 200 \mathrm{H}$ で 6 個製作した。

Table 1 Experimental parameter

\begin{tabular}{|c|c|c|c|c|}
\hline Series & $\begin{array}{c}\beta \\
\text { H } / 2 \mathrm{a}\end{array}$ & $\begin{array}{c}2 \mathrm{a} \\
\mathrm{mm}\end{array}$ & $\begin{array}{c}\mathrm{S} \\
\mathrm{cm}^{2}\end{array}$ & Numbers \\
\hline A & 20.0 & 10 & 8.0 & 40 \\
\hline B & 14.3 & 14 & 11.2 & 40 \\
\hline C & 10.0 & 20 & 16.0 & 40 \\
\hline D & 8.0 & 25 & 20.0 & 40 \\
\hline E & 5.0 & 40 & 32.0 & 40 \\
\hline F & 4.0 & 50 & 40.0 & 38 \\
\hline G & 3.45 & 58 & 46.4 & 38 \\
\hline H & 2.94 & 68 & 54.4 & 38 \\
\hline I & 2.5 & 80 & 64.0 & 38 \\
\hline J & 2.0 & 100 & 80.0 & 38 \\
\hline
\end{tabular}

\section{(4) 加力実験}

実験は1993年4月から1994年12月にかけて行った。加力は 1 ロット 毎にA〜Jシリーズについて行い、A〜Eシリーズについて各40体、F〜 Jシリーズについて38体について加力した。材令は 28 日を標準とし、 試験体の加力に先立ちテストピースの圧縮武験を行い試験体の圧縮 強度を求めた。

\section{2 英瞼結果}

\section{（1）〈さび破壊と压縮すべり破壊}

実験結果の解析をするに当たり、加力条件により破壊形式が異な るため、くさび破壊と压縮すべり破壊形式について述へる。くさび 理論を文献 1 から再揭すると、圧裂試験における部分压縮強度 $\mathrm{p} の$ 解は $\mathrm{t}=\cot \alpha$ をパラメーターとして（1）式により与えられる。 （記号はFig 3 参照）

$$
\begin{aligned}
\mathrm{p}=\frac{\mathrm{At}^{2}+\mathrm{Bt}+\mathrm{C}}{\mathrm{t}}-\mu \\
\text { ここに、 } \mathrm{A}=\tau \mathrm{o}-\mu \mathrm{Ft} \\
\mathrm{B}=(\mu \beta-1) \mathrm{Ft} \\
\mathrm{C}=\tau \mathrm{o}+\beta \mathrm{Ft} \\
\tau \mathrm{o}=\frac{\left(1+\mu^{2}\right)^{1 / 2}-\mu}{2} \mathrm{Fc} \\
\mu=\tan \phi \\
\beta=\mathrm{h} / \mathrm{a}
\end{aligned}
$$

（1）式の極小值を与える $\mathrm{t}$ oは $\mathrm{t}>\mu$ の範囲で

$$
\frac{d p}{d t}=0
$$

より、

$\mathrm{t} \mathrm{o}=\mu+\left\{\mu^{2}+(\mathrm{B} \mu+\mathrm{C}) / \mathrm{A}\right\}^{1 / 2}$

となる。くさびが成立するための幾何学的条件は

$$
\beta \geqq \mathrm{to}
$$

であるから（6）式の範囲ではくさび破壊形式となって部分厌縮強 度は (5) 式を (1) 式に代入して、

$\mathrm{p}_{\text {min }}=\mathrm{B}+2 \mathrm{~A} \mu+2\left\{(\mathrm{~A} \mu)^{2}+\mathrm{AB} \mu+\mathrm{AC}\right\}^{1 / 2}$ なる。このとき $\beta$ の值は（5）式を（6）式に代人して、

$$
\begin{aligned}
& \beta \geqq \frac{\mathrm{K}+\left\{\mathrm{K}^{2}+4 \mathrm{~A}^{2}\right\}^{1 / 2}}{2 \mathrm{~A}} \\
& こ こ に 、 \mathrm{~K}=2 \mathrm{~A} \mu+\mu^{2} \mathrm{Ft}+\mathrm{Ft}
\end{aligned}
$$

となり、くさび破壊を生ずる $\beta$ の下限值 $\beta$ oは $\phi$ と $\mathrm{Fttをパラメー夕}$ 一としてTable 2 のうに算定される。

Table 2 Limit value of $\beta(=\mathrm{h} / \mathrm{a})$

\begin{tabular}{|c|c|c|c|c|c|c|}
\hline \multirow{2}{*}{$\begin{array}{l}\text { deg } \\
\text { deg }\end{array}$} & 0.04 & \multicolumn{5}{|c|}{ Ftt $(\mathrm{Ft} / \mathrm{Fc})$} \\
\cline { 3 - 7 } & 0.05 & 0.06 & 0.07 & 0.08 & 0.09 \\
\hline 37 & 2.24 & 2.31 & 2.39 & 2.47 & 2.56 & 2.66 \\
\hline 39 & 2.36 & 2.45 & 2.54 & 2.64 & 2.75 & 2.87 \\
\hline 41 & 2.50 & 2.60 & 2.71 & 2.83 & 2.96 & 3.12 \\
\hline 43 & 2.66 & 2.77 & 2.90 & 3.05 & 3.22 & 3.42 \\
\hline 45 & 2.83 & 2.97 & 3.14 & 3.32 & 3.54 & 3.80 \\
\hline 47 & 3.03 & 3.21 & 3.41 & 3.65 & 3.95 & 4.30 \\
\hline 49 & 3.27 & 3.49 & 3.75 & 4.07 & 4.48 & 5.01 \\
\hline 51 & 3.54 & 3.83 & 4.18 & 4.64 & 5.24 & 6.08 \\
\hline 53 & 3.88 & 4.26 & 4.75 & 5.44 & 6.42 & 7.91 \\
\hline 55 & 4.30 & 4.83 & 5.57 & 6.70 & 8.58 & 12.3 \\
\hline 57 & 4.85 & 5.63 & 6.86 & 9.04 & 14.0 & 35.0 \\
\hline
\end{tabular}

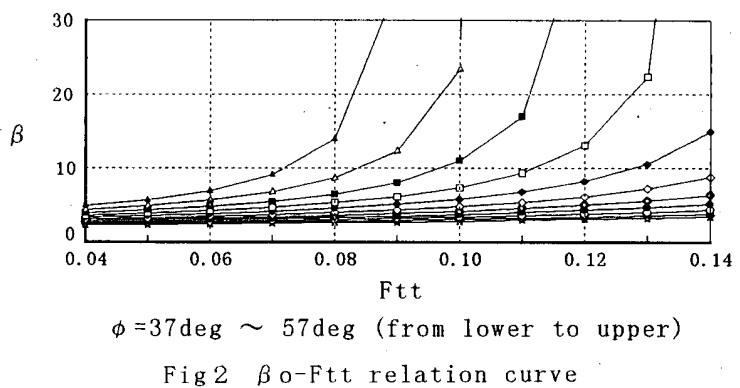



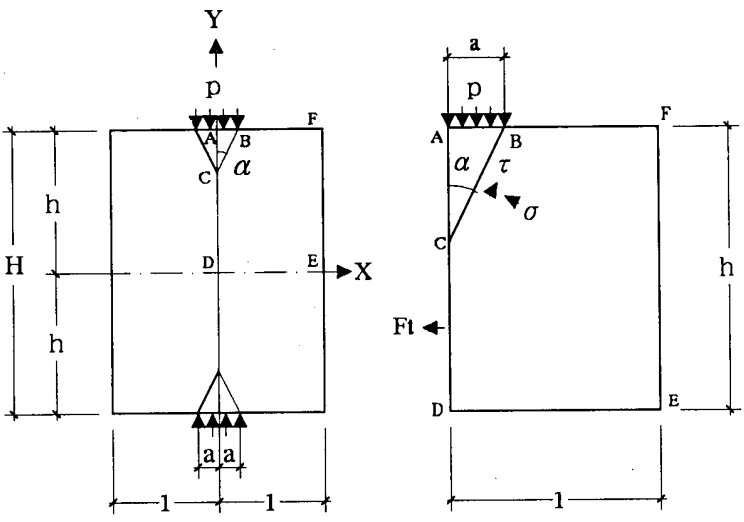

Fig 3 Mode of fracture in partial compression according to "Wedge Theory" and stress relations along fracture lines

つぎに、 $\mathrm{t} 0<\beta$ の場合は文献 3 で述へたように破壊形式はFig 4 に 示す环縮すべり破壊となり、pの值は（１０）式のように求めら れる。

$$
\mathrm{p}=\frac{\tau_{0} \cdot \cos \phi}{\cos \theta \cdot \sin (\theta-\phi)}
$$

(1 0 ) 式の分母は、 $2 \theta-\phi=90^{\circ}$ のとき最大值 $(1-\sin \phi)$ / 2 となり、pの下限值は、モール・クーロンの破壊条件を適用し $\tau$.

$$
p_{\text {min }}=\frac{2 \tau o \cdot \cos \phi}{1-\sin \phi}=\mathrm{Fc}
$$

となり、このときのすべり角は、

$$
\theta=45^{\circ}+\phi / 2
$$

で与えられる。

$\beta \geqq \beta$ oのときは $(5)$ 式、 $\beta<\beta$ oのときは $\left(\begin{array}{ll}1 & 0\end{array}\right)$ 式 $(\theta=$ ta $\mathrm{n}^{-1} \beta$ として) を用いて、 $\phi=55^{\circ} 、 \mathrm{Ftt}=0.05$ のときのp/Fc と $\beta(\beta=1.5 \sim 20)$ の関係を図示するとFig4 (b)図が得られる。 （１１０）式では $\beta$ が 2.5 以下になると、 $\mathrm{p} / \mathrm{Fc}$ の值は急激に上昇す るようになる。しかし、実験の結果ではこのような現象はみられず、 文献 4 においても $\beta=2 \sim 1.5$ 程度まではなだらかな上昇傾向を たどっていることが確認されている。 $\tan ^{-1} \beta$ が（1 12 ) 式によって得られるすべり角度 $\theta$ 以下になるとす べり角は一定値 $\theta$ となるとして Fig4 (a-1)に示すようなすべり線を 想定すると ( $\left.\begin{array}{ll}1 & 1\end{array}\right)$ 式で示されるように $\mathrm{p} / \mathrm{Fc}=1$ となる。この関係 はFig4（a-2)に示す $\beta$ まで続き、この $\beta$ 以下では両側のすべり線が 同一の繸方向切断面内に存在しない範囲ができるため破壊に要する 荷重が増大し、 $\mathrm{p} / \mathrm{Fc}$ の值が上昇していくと考えられる。 $\phi=55^{\circ}$ 、 $\mathrm{Ftt}=0.05$ のときに Fig4（a-2)において $\beta=1.59$ となる。 以上の考察により実験值の解析に当たっては、 $\beta \geqq \beta$ ○皇をは (5) 式、 $\beta<\beta$ ○のときは $\left(\begin{array}{ll}1 & 0\end{array}\right)$ 式、 $\tan ^{-1} \beta<\theta$ のときは $\mathrm{p} / \mathrm{F}$ $\mathrm{c}=1$ として理論值を算定することとする。
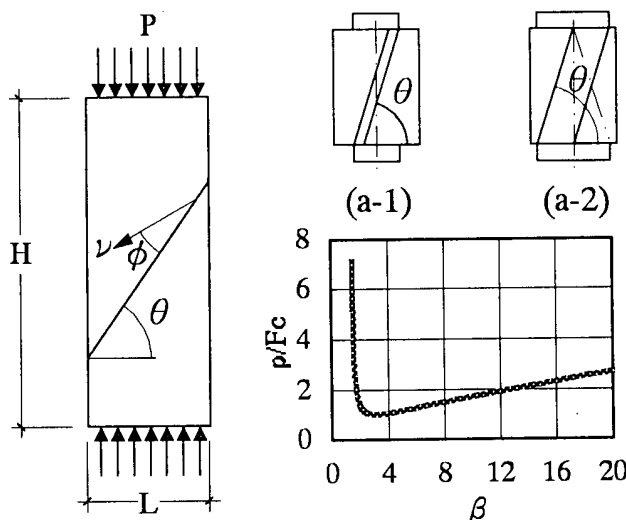

(a-1)

(a-2)

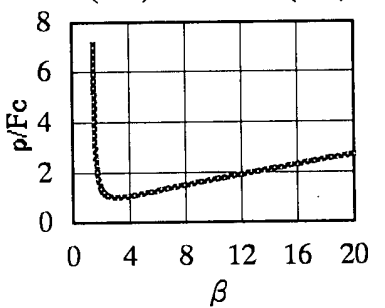

(b)

Fig 4 Failure mechanism in pure cmpression of

a rectangular disk

$(a-1,2)$ Slip failure line at $\tan ^{-1}(h / a)<\theta$

(b) $\mathrm{p} / \mathrm{Fc}-\beta$ relation curve

\section{(2) 実験結果}

压裂試験は 26 ロット、10 シリーズ、合計 390 個の試験体に ついて行った。各ロットのテストピースの王縮武験結果の分布状況 をFig 2 1、Fig 22 に示す。

Case 1は 1〜12 ロットまでの 72 体のテストピースの試験結果て、、 水セメント比を $60 \%$ とした。Case 2は 13 ～ 26 ロットまでの 84 体のテストピースの試験結果で水セメント比を $65 \%$ とした。 水セメント比を変えたのは気温の変動による施工性と強度の補正を 考虑したためである。厈裂試験結果の解析にはテストピース 6 体の 上下值をカットした 4 体の压縮強度の平均值を用いた。

Fig 5 Fig 9 に压裂テストの実験結果を緃軸に $\mathrm{p} / \mathrm{Fc} 、$ 横軸に $\beta$ を とって表示する。図中の黒点は実験結果の分布を示し、太線の上下 は央験結果の平均值から母平均の信頼区間を $\mathrm{t}$ - 検定により信頼率 $95 \%$ で推定した上下限值を結んだ曲線、中央が実験結果の平均值 を結んだ曲線をそれぞれ示している。細実線は前述の理論式を用い て算定した結果である。

実駼結果との比較に用いた理論値のパラメータの組合せは、内部

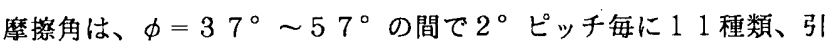
張強度比は、各 $\phi に$ 対してFtt $=0.01 \sim 0.9$ 間で 0.01 ピッ チで 9 種類の合計 99 種類である。この内、実験値の $\mathrm{t}$-検定にお ける信頼率 $95 \%$ の間に $\beta$ の全部について合格する組合せは、唯一 $\phi=55^{\circ} 、 \mathrm{Ftt}=0.05$ の場合であり、このときの理論值に対す る実験結果の值を $\mathrm{F}$-検定した結果は、 $5 \%$ の有意差で $\beta$ の値によ って実験值がばらつくことはなかった。

この結果から

$1:$ 母平均の推定值が最もよく適合するのは、 $\phi=55^{\circ} 、 \mathrm{Ftt}=0.05$ のものである。

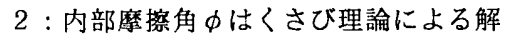
$\phi=57.5^{\circ}$ に近ずくほど母平均の推定分布が理論解に 近づいていることが分かった。

（＊実験結果の図表を挟み、後に続く） 


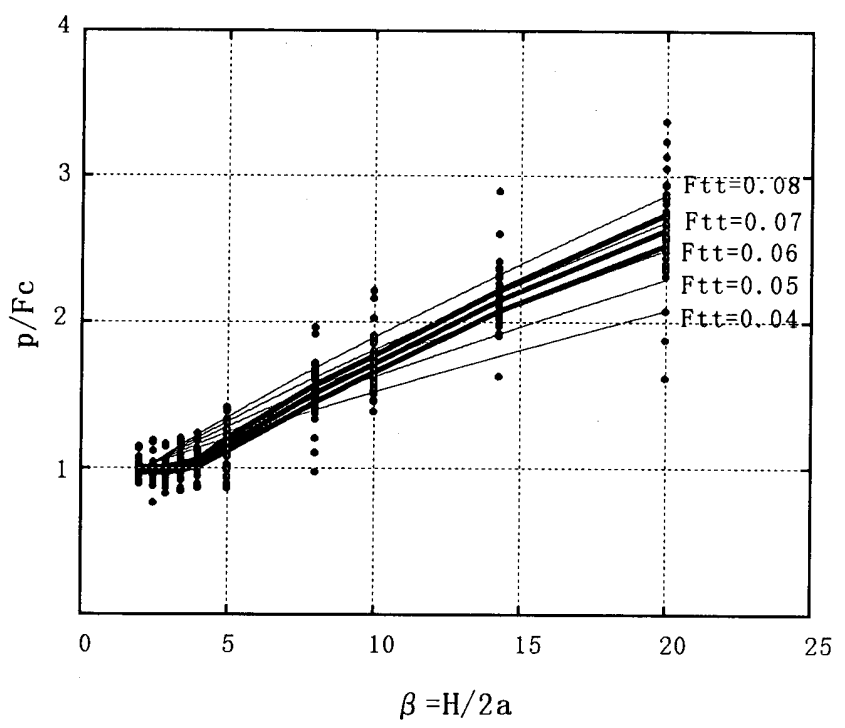

Fig $5 \phi=37 \mathrm{deg}$

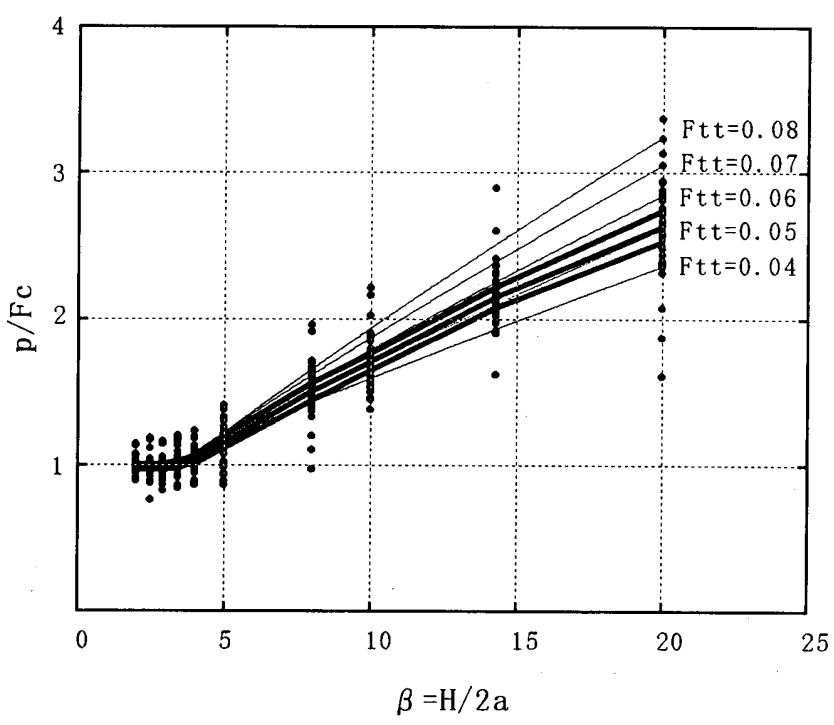

Fig $7 \quad \phi=51 \mathrm{deg}$

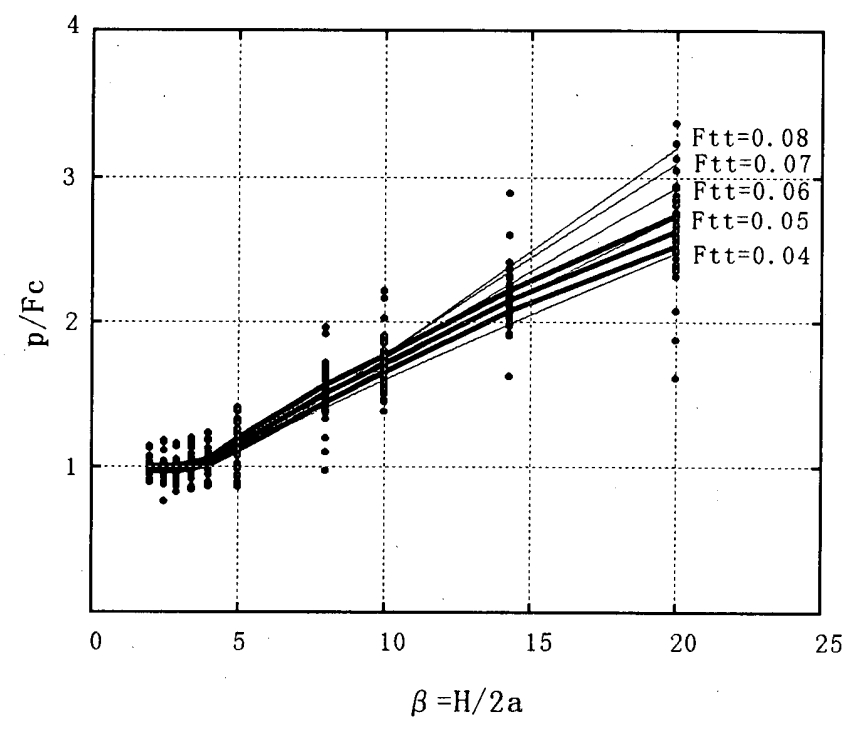

Fig $9 \phi=57 \mathrm{deg}$

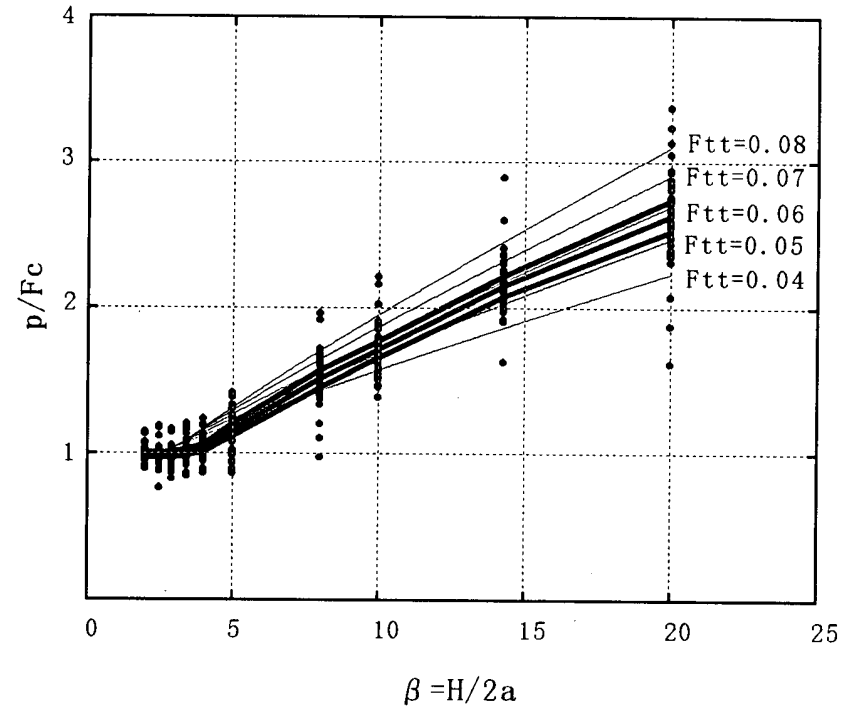

Fig $6 \phi=45 \mathrm{deg}$

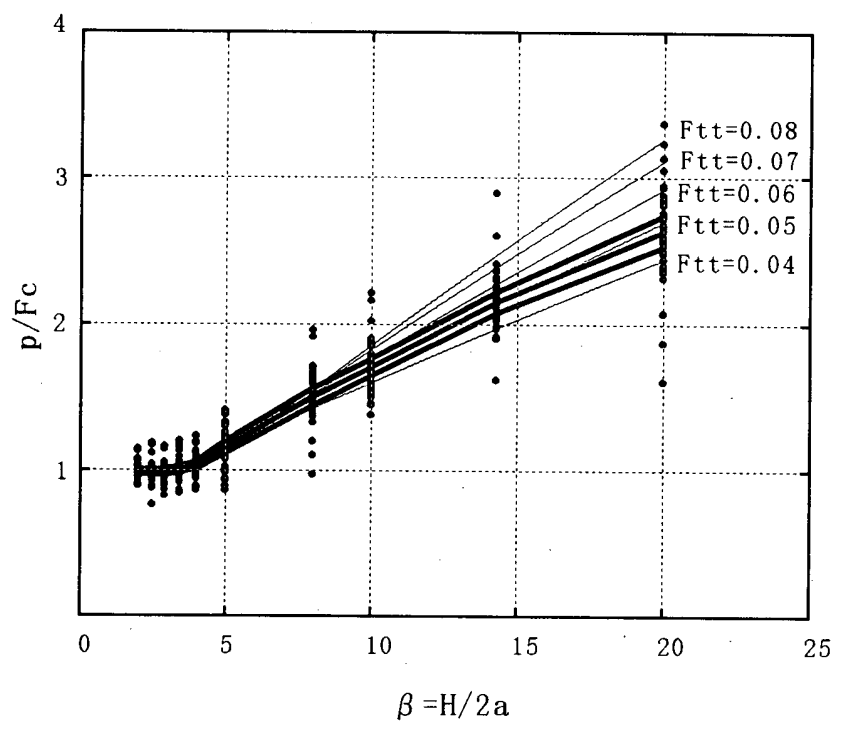

Fig $8 \phi=55$ deg

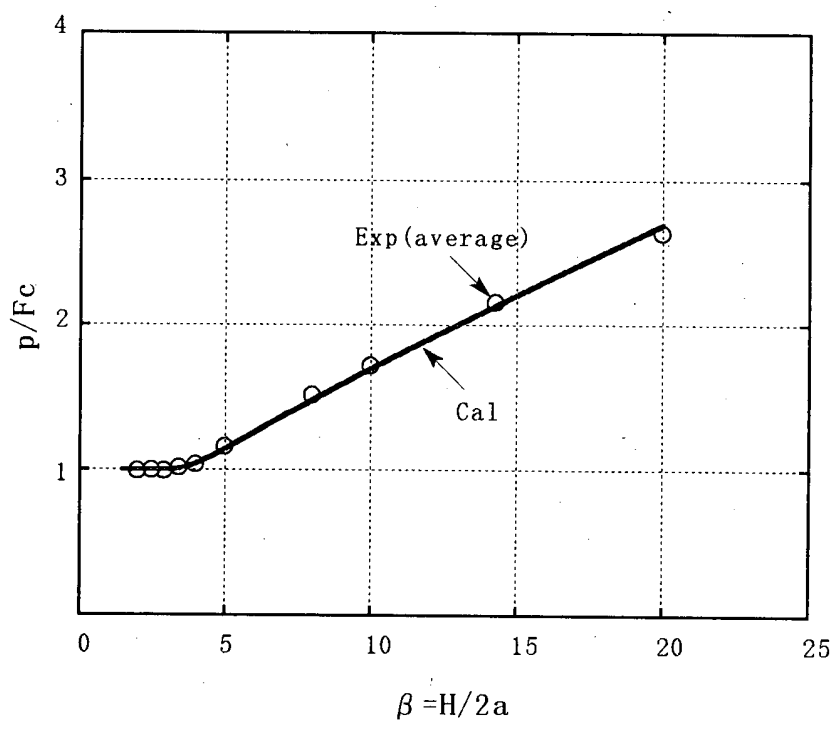

Fig $10 \phi=55 \mathrm{deg}, \quad \mathrm{Ft}=0.05 \mathrm{Fc}$ 


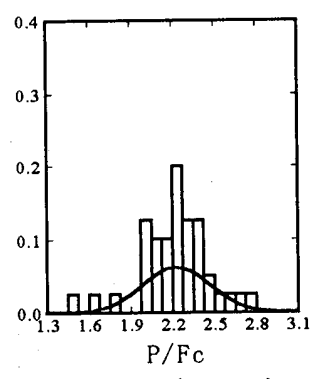

Fig 11 A series

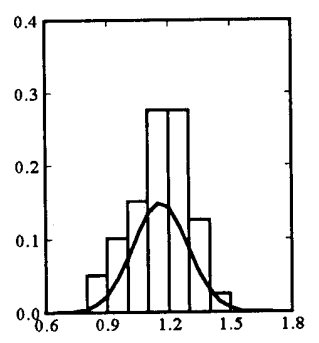

$\mathrm{P} / \mathrm{Fc}$

Fig 15 E series

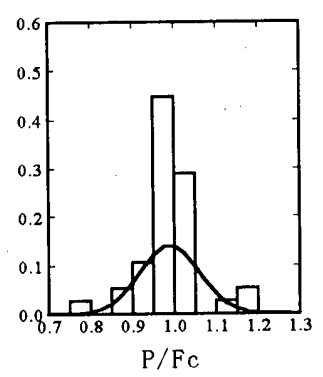

Fig 19 I series

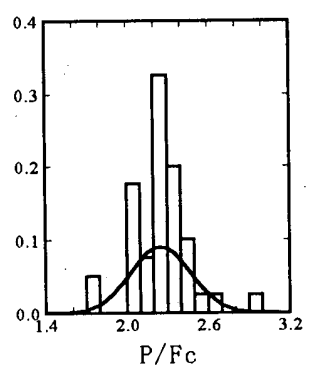

Fig 12 B series

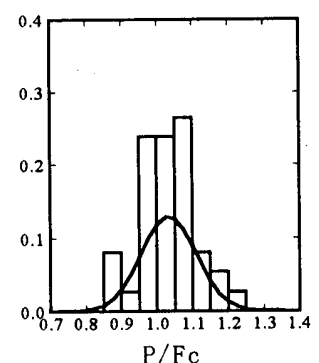

Fig $16 \quad \mathrm{~F}$ series

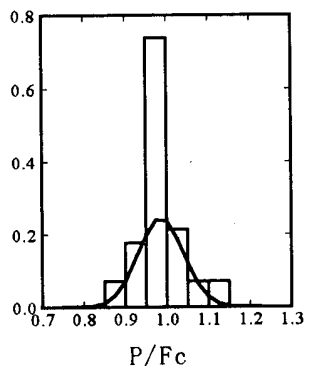

Fig $20 \mathrm{~J}$ series

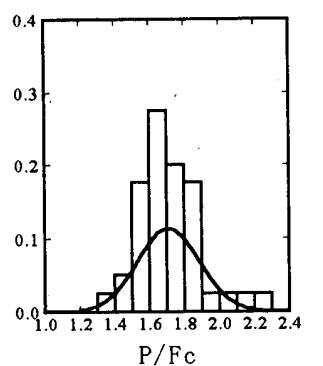

Fig 13 C series

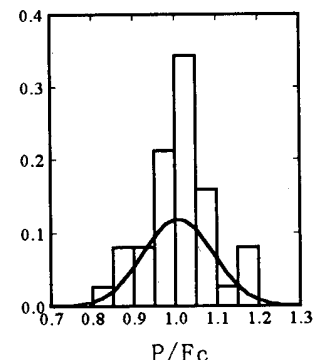

Fig 17 G series

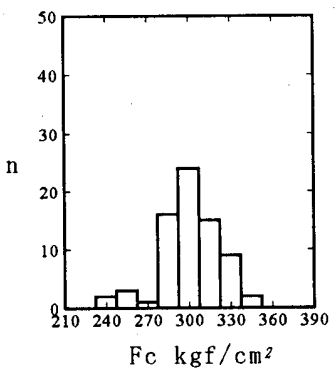

Fig 21 Fc histgram of test piecies Case1 $\quad(x=60 \%)$

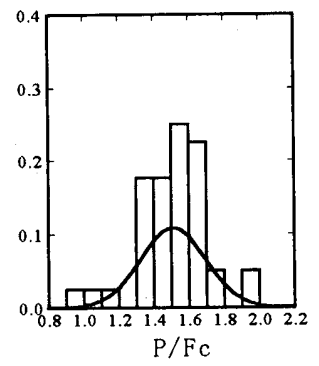

Fig 14 D series

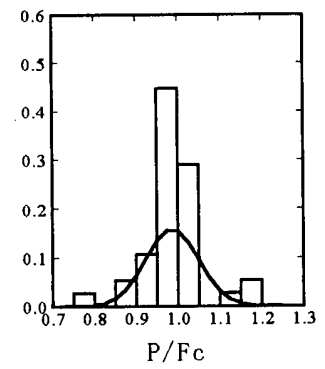

Fig 18 H series

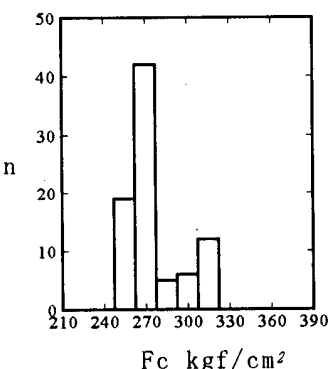

Fig 22 Fc histgram of test piecies Case 2 $\quad(x=65 \%)$

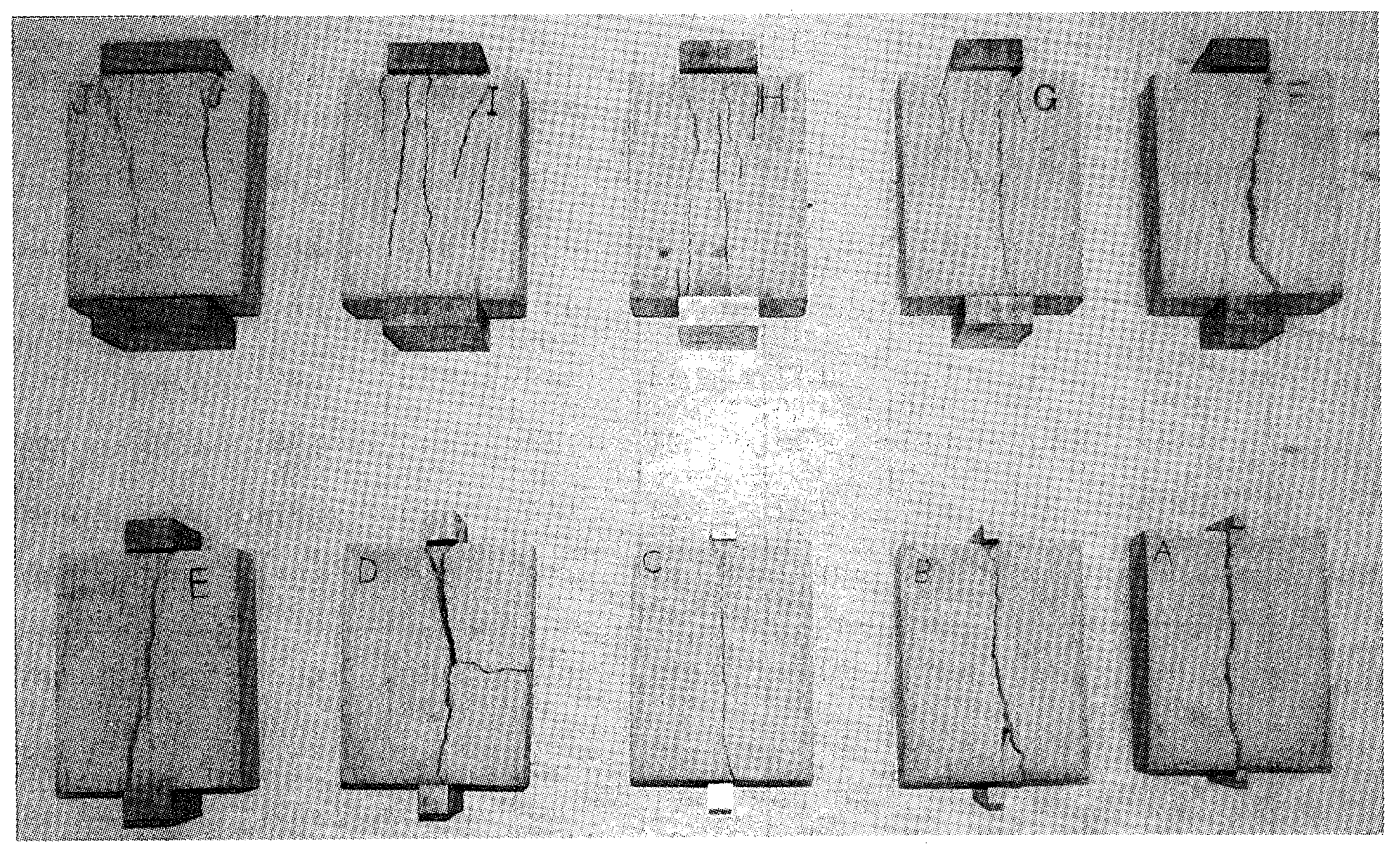

Fig 23 Photograph of test results 
Table 3 Experimental data

\begin{tabular}{|c|c|c|c|c|c|c|c|c|c|c|c|}
\hline & $\mathrm{A}$ & $\bar{B}$ & $\mathrm{C}$ & $\mathrm{D}$ & E & $\mathrm{F}$ & $\mathrm{G}$ & $\overline{\mathrm{H}}$ & I & $\mathbf{J}$ & \\
\hline \multirow[b]{3}{*}{ ロット } & $\begin{array}{c}\beta \\
20.00 \\
\end{array}$ & $\begin{array}{c}\beta \\
14.30 \\
\end{array}$ & $\begin{array}{c}\beta \\
10.00 \\
\end{array}$ & $\begin{array}{c}\beta \\
8.00 \\
\end{array}$ & $\begin{array}{c}\beta \\
5.00 \\
\end{array}$ & $\begin{array}{c}\beta \\
4.00 \\
\end{array}$ & $\begin{array}{c}\beta \\
3.45 \\
\end{array}$ & $\begin{array}{c}\beta \\
2.94 \\
\end{array}$ & $\begin{array}{c}\beta \\
2.50 \\
\end{array}$ & $\begin{array}{c}\beta \\
2.00\end{array}$ & \\
\hline & $\begin{array}{l}\text { As } \\
8.0 \\
\end{array}$ & $\begin{array}{c}\text { As } \\
11.2 \\
\end{array}$ & $\begin{array}{c}\text { As } \\
16.0 \\
\end{array}$ & $\begin{array}{c}\text { As } \\
20.0 \\
\end{array}$ & $\begin{array}{c}\text { As } \\
32.0 \\
\end{array}$ & $\begin{array}{c}\text { As } \\
40.0 \\
\end{array}$ & $\begin{array}{c}\text { As } \\
46.4 \\
\end{array}$ & $\begin{array}{c}\text { As } \\
54.4 \\
\end{array}$ & $\begin{array}{c}\text { As } \\
64.0 \\
\end{array}$ & $\begin{array}{c}\text { As } \\
80.0 \\
\end{array}$ & \\
\hline & $\sigma / \mathrm{Fc}$ & $\sigma / \mathrm{Fc}$ & $\sigma / \mathbf{F c}$ & $\sigma / \mathbf{F c}$ & $\sigma / \mathrm{Fc}$ & $\sigma / \mathrm{Fc}$ & $\sigma / \mathrm{Fc}$ & $\sigma / \mathrm{Fc}$ & $\sigma / \mathrm{Fc}$ & $\sigma / \mathrm{Fc}$ & $\mathrm{Fc}$ \\
\hline 1 & $\begin{array}{l}2.67 \\
2.07\end{array}$ & $\begin{array}{l}2.25 \\
190\end{array}$ & 1.61 & 1.10 & 0.94 & 0.97 & 0.96 & 1.01 & 1.03 & 1.07 & 332.8 \\
\hline 2 & $\begin{array}{l}2.07 \\
2.39\end{array}$ & $\begin{array}{l}1.90 \\
191\end{array}$ & $\begin{array}{l}1.55 \\
158\end{array}$ & 0.97 & $\begin{array}{l}0.89 \\
0.86\end{array}$ & & & & & & 332.8 \\
\hline 2 & & 1.91 & 1.58 & 1.45 & 0.86 & $\begin{array}{l}0.96 \\
0.89\end{array}$ & $\begin{array}{l}0.86 \\
1.00\end{array}$ & $\begin{array}{l}0.92 \\
0.89\end{array}$ & $\begin{array}{l}1.02 \\
1.00\end{array}$ & 0.98 & $\begin{array}{l}313.8 \\
313.8\end{array}$ \\
\hline 3 & 1.61 & 1.62 & 1.38 & 1.49 & 0.98 & 0.86 & 0.84 & 0.82 & 0.76 & 0.90 & 322.1 \\
\hline 3 & 1.87 & 1.62 & 1.46 & 1.33 & 0.93 & & & & & & 322.1 \\
\hline 4 & 2.55 & 2.18 & 1.76 & 1.51 & 1.17 & 1.00 & 0.93 & 0.96 & 0.98 & 0.98 & 320.2 \\
\hline 4 & & & & & & 1.02 & 0.97 & 0.92 & 0.96 & 0.99 & 320.2 \\
\hline 5 & 2.68 & 2.26 & 1.75 & 1.54 & 1.09 & 0.94 & 0.86 & 0.93 & 0.87 & 0.98 & 305.6 \\
\hline 5 & 2.48 & 2.18 & 1.87 & 1.38 & 1.00 & & & & & & 305.6 \\
\hline 6 & 2.71 & 2.12 & 1.88 & 1.65 & 1.24 & 1.13 & 1.09 & 1.04 & 1.01 & 1.06 & 253.8 \\
\hline 6 & & & & & & 1.10 & 1.02 & 1.00 & 1.03 & 1.01 & 253.8 \\
\hline 7 & 2.67 & 2.15 & 1.80 & 1.60 & 1.21 & 1.02 & 1.05 & 1.04 & 1.04 & 0.99 & 298.6 \\
\hline 7 & 2.35 & 1.91 & 1.86 & 1.62 & 1.19 & & & & & & 298.6 \\
\hline 8 & 2.59 & 2.14 & 1.73 & 1.62 & 1.16 & 1.03 & 1.02 & 1.00 & 1.01 & 0.98 & 287.3 \\
\hline 8 & & & & & & 1.02 & 1.06 & 1.04 & 0.95 & 0.91 & 287.3 \\
\hline 9 & 3.23 & 2.89 & 2.21 & 1.91 & 1.41 & 1.23 & 1.16 & 1.05 & 1.11 & 0.96 & 297.8 \\
\hline 9 & 3.37 & 2.60 & 2.16 & 1.96 & 1.39 & & & & & & 297.8 \\
\hline 10 & 2.63 & 2.21 & 2.02 & 1.71 & 1.23 & 1.06 & 1.01 & 1.01 & 0.97 & 0.90 & 299.4 \\
\hline 10 & & & & & & 1.07 & 1.00 & 0.95 & 0.93 & 0.95 & 299.4 \\
\hline 11 & 2.48 & 2.16 & 1.73 & 1.38 & 1.07 & 1.02 & 0.92 & 1.01 & 0.92 & 0.97 & 290.0 \\
\hline 11 & 2.56 & 2.16 & 1.71 & 1.55 & 1.15 & & & & & & 290.0 \\
\hline 12 & 2.68 & 2.30 & 1.85 & 1.61 & 1.15 & 1.02 & 1.00 & 0.99 & 1.00 & 0.99 & 291.0 \\
\hline 12 & & & & & & 0.99 & 0.97 & 0.99 & 1.00 & 0.98 & 291.0 \\
\hline 13 & 2.94 & 2.26 & 1.65 & 1.56 & 1.26 & 1.12 & 1.06 & 1.00 & 1.03 & 0.97 & 259.0 \\
\hline 13 & 3.05 & 2.41 & 1.78 & 1.42 & 1.31 & & & & & & 259.0 \\
\hline 14 & 2.74 & 1.98 & 1.59 & 1.37 & 1.22 & 1.09 & 1.01 & 1.02 & 1.01 & 1.03 & 274.8 \\
\hline 14 & & & & & & 1.06 & 1.02 & 1.02 & 1.01 & 1.03 & 274.8 \\
\hline 15 & 2.31 & 1.99 & 1.67 & 1.56 & 1.07 & 0.97 & 0.86 & 0.86 & 0.92 & 0.94 & 318.2 \\
\hline 15 & 2.40 & 2.05 & 1.56 & 1.54 & 1.09 & & & & & & 318.2 \\
\hline 16 & 2.76 & 2.03 & 1.65 & 1.37 & 1.19 & 1.00 & 1.00 & 0.98 & 0.98 & 1.00 & 315.1 \\
\hline 16 & & & & & & 0.99 & 1.03 & 0.97 & 1.00 & 0.99 & 315.1 \\
\hline 17 & 2.44 & 2.12 & 1.61 & 1.40 & 1.33 & 1.10 & 1.01 & 1.02 & 0.97 & 0.96 & 262.3 \\
\hline 17 & 2.58 & 2.10 & 1.60 & 1.51 & 1.30 & & & & & & 262.3 \\
\hline 18 & 2.93 & 2.31 & 1.70 & 1.47 & 1.23 & 1.03 & 1.13 & 1.01 & 1.00 & 0.99 & 274.2 \\
\hline 18 & & & & & & 1.06 & 1.05 & 0.99 & 1.00 & 1.00 & 274.2 \\
\hline 19 & 2.72 & 2.14 & 1.60 & 1.59 & 1.20 & 1.07 & 1.02 & 0.99 & 0.98 & 0.96 & 260.3 \\
\hline 19 & 2.84 & 2.21 & 1.64 & 1.64 & 1.21 & & & & & & 260.3 \\
\hline 20 & 3.13 & 2.37 & 1.90 & 1.67 & 1.38 & 1.19 & 1.18 & 1.16 & 1.17 & 1.14 & 265.9 \\
\hline 20 & & & & & & 1.18 & 1.20 & 1.14 & 1.18 & 1.13 & 265.9 \\
\hline 21 & 2.49 & 1.92 & 1.52 & 1.33 & 0.98 & 0.87 & 0.91 & 0.86 & 0.89 & 0.89 & 301.7 \\
\hline 21 & 2.37 & 1.97 & 1.45 & 1.20 & 1.02 & & & & & & 301.7 \\
\hline 22 & 2.68 & 2.12 & 1.68 & 1.48 & 1.13 & 0.99 & 0.97 & 1.02 & 0.98 & 0.99 & 266.3 \\
\hline 22 & & & & & & 0.99 & 1.00 & 0.97 & 1.00 & 1.00 & 266.3 \\
\hline 23 & 2.85 & 2.24 & 1.72 & 1.51 & 1.18 & 1.05 & 1.05 & 1.00 & 1.01 & 1.03 & 263.1 \\
\hline 23 & 2.72 & 2.14 & 1.80 & 1.60 & 1.24 & & & & & & 263.1 \\
\hline 24 & 2.88 & 2.32 & 1.85 & 1.70 & 1.24 & 1.07 & 1.02 & 0.98 & 1.00 & 0.98 & 267.0 \\
\hline 24 & & & & & & 1.06 & 1.05 & 1.00 & 0.99 & 0.99 & 267.0 \\
\hline 25 & 2.81 & 2.36 & 1.80 & 1.67 & 1.26 & 1.06 & 0.99 & 0.97 & 0.93 & 0.95 & 273.2 \\
\hline 25 & 2.66 & 2.24 & 1.70 & 1.60 & 1.23 & & & & & & 273.2 \\
\hline 26 & 2.68 & 2.13 & 1.53 & 1.43 & 1.15 & 0.99 & 0.97 & 0.97 & 0.97 & 0.97 & 267.3 \\
\hline 26 & 2.81 & 2.02 & 1.50 & 1.40 & 1.12 & & & & & & 267.3 \\
\hline 平均 $\mu$ & 2.634 & 2.150 & 1.710 & 1.510 & 1.160 & 1.033 & 1.007 & 0.986 & 0.989 & 0.986 & 1.427 \\
\hline 分散 $\sigma^{\wedge} 2$ & 0.105 & 0.049 & 0.031 & 0.034 & 0.018 & 0.006 & 0.007 & 0.004 & 0.005 & 0.003 & \\
\hline $\mathrm{n}$ & 40 & 40 & 40 & 40 & 40 & 38 & 38 & 38 & 38 & 38 & 390 \\
\hline 偏差平方和 & 4.204 & 1.965 & 1.223 & 1.346 & 0.711 & 0.230 & 0.254 & 0.158 & 0.189 & 0.102 & 10.382 \\
\hline 不偏分散 V & 0.108 & 0.050 & 0.031 & 0.035 & 0.018 & 0.006 & 0.007 & 0.004 & 0.005 & 0.003 & 0.027 \\
\hline$\sqrt{ } \mathrm{V}$ & 0.328 & 0.224 & 0.177 & 0.186 & 0.135 & 0.079 & 0.083 & 0.065 & 0.071 & 0.052 & \\
\hline $\operatorname{tn}-1(0.05)$ & 2.023 & 2.023 & 2.023 & 2.023 & 2.023 & 2.026 & 2.026 & 2.026 & 2.026 & 2.026 & \\
\hline 95\%信頼区間上限 & 2.739 & 2.222 & 1.767 & 1.569 & 1.203 & 1.059 & 1.034 & $\begin{array}{ll}1.008 \\
\end{array}$ & 1.012 & 1.004 & \\
\hline 95\%信頼区間下限 & 2.529 & 2.078 & 1.654 & 1.450 & 1.117 & 1.007 & 0.979 & 0.965 & 0.965 & 0.969 & \\
\hline
\end{tabular}


Fig 10 は $\phi=55^{\circ} 、 \mathrm{Ftt}=0.05$ の值を用いた計算值と実験 の平均值を比較したものであり非常によく一致していることが分か る。

Fig 1 1 Fig 20 は各シリーズの実験結果のヒストグラムに実験 值の平均値と分散を用いて正規分布を算定した結果を合わせて図示 したもので、相対度数を緃軸に用いている。

Fig 23 の写真は各シリーズの試験体の代表的破壊例を示す。理論 的には $\phi=55^{\circ} 、 \mathrm{Ftt}=0.05$ の場合は、A E までがくさび破 壊（割裂形の破壊）、F〜J は圧縮すへり破壊（圧壊形の破壊）とな っているが実験結果は概ねこの事実に合っている。 Table 3 に実験結果の一覧を示す。

\section{3. 理論的背最}

コンクリートの引張強度を推定する手段として円柱の割裂試験 （JISA1113）が行われているがこの試験方法にくさび理論の適用を 試みる。すなわち、くさび理論において支圧面の幅 2 aを小さくし ていくと円柱の割裂武験と同様の結果が得られるはずである。（7） 式を変形して

$$
\begin{aligned}
\mathrm{p} / \beta= & (\mu-1 / \beta) \mathrm{Ft}+2 \mathrm{~A} \mu / \beta \\
& +2\{(\mathrm{~A} \mu / \beta) 2+(\mathrm{A} \mu 2 / \beta-\mathrm{A} \mu / \beta 2 \\
& +(\mathrm{A} \tau \mathrm{o} / \beta 2+\mathrm{AFt} / \beta)\}^{1 / 2}
\end{aligned}
$$

従って、

$\lim (p / \beta)=\mu \mathrm{Ft} \quad(\beta \rightarrow \infty)$

が得られる。すなわち $\beta$ が大きい範囲では近似的に

$\mathrm{p} / \beta=\mu \mathrm{Ft}$

が成立する。

(1 5 ) 式をさらに変形すると

$\beta=\mathrm{H} / 2 \mathrm{a} 、 \mathrm{H}=\mathrm{d} 、 \mathrm{P}=2 \mathrm{a} \mathrm{p}$

より

$\mathrm{p} / \beta=2$ a $\mathrm{p} / \mathrm{H}=\mathrm{P} / \mathrm{d}=\mu \mathrm{Ft}$

となる。

一方割裂試験のコンクリートの引張強度は

$\mathrm{F} \mathrm{t}^{\prime}=2 \mathrm{P} / \pi \mathrm{d}$

であるから、（1 6 ）（1 7 ）式から P / d を消去して、

$\mu=\pi \mathrm{Ft} \mathrm{t}^{\prime} / 2 \mathrm{Ft}$

ここで、F $\mathrm{t}^{\prime}=\mathrm{Ft}$ tすす机ば、

$\mu=\pi / 2$

が得ら机、内部摩摖角 $\phi$ は

$\phi=\tan ^{-1}(\pi / 2)=57.5^{\circ}$

となり、実験により得られた内部摩擦角 $\phi=55^{\circ}$ は理論解にほぼ 近い值となっていることが分かる。

\section{4. 実験值の道用例}

央験により求められた、 $\phi=55^{\circ} 、 F t t=0.05$ をいくつか の命題に適用する。

\section{1 真の一軸圧缩強度}

真の一軸圧縮強度は、（１２２）式に $\phi$ の值を代入して

$$
\theta=72.5^{\circ}
$$

底面の径と高さの比が

$$
\mathrm{H} / \mathrm{d}=\tan \left(\begin{array}{ll}
72.5 \\
2
\end{array}\right)=3.17
$$

程度で与えられると考えられる。

さて、従来用いてきた $\phi=37^{\circ}$ のときは、 $\theta=45^{\circ}+37^{\circ}$

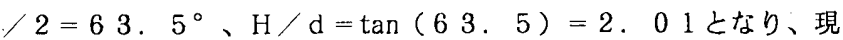
行のコンクリート強度試験用のテストピースの高さ・径比に一致し ている。しかし、破壊面が $\phi>37^{\circ}$ の場合はテストピースの圧縮 強度（の最小値）は端面の拘束効果によって上昇することになる。

既往の研究（文献 5 ）によれば、一軸圧縮強度はテストピースの $\mathrm{H} / \mathrm{d}$ によって変化し、一般的に $\mathrm{H} / \mathrm{d}$ が増加すると圧縮強度は低 下するが、 $\mathrm{H} / \mathrm{d}=3 \sim 4$ 以降は概ね一定となると報告されている。 上記の算定值を受入れるとすればこの現象が概念的にではあるが理 解することが出来る。

\section{2 円柱による割裂眭䀫}

米国における円柱割裂武験規準（ASTM-C649-62T）で使われる試験 片寸法、 $2 \mathrm{a}=0.5 \mathrm{i} \mathrm{n} 、 \mathrm{~d}=6 \mathrm{i}$ nにおいて、F $\mathrm{t}^{\prime} / \mathrm{F} \mathrm{c}$ 值 は平均 0.1 とされている（1 軸引張強度は0.085 0.10F ）（文献 $6)$ 。今回の実験で得られた $\phi=55^{\circ} 、 F t t=0.05$ を用い

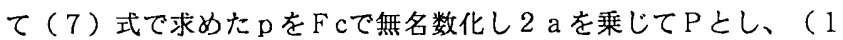
7 ）式に代入すると割裂試験の見かけの引張強度比

$$
\mathrm{Ftt}=\mathrm{Ft}^{\prime} / \mathrm{Fc}
$$

を求めることができる。

このようにして求めた $\beta$ と F tt' の值を Fig 24 に示す。この図か ら計算結果は $\beta=12$ の時 $\mathrm{F} \mathrm{tt} \mathrm{t}^{\prime}=0.101$ となり、上記の実験結 果と一致する。

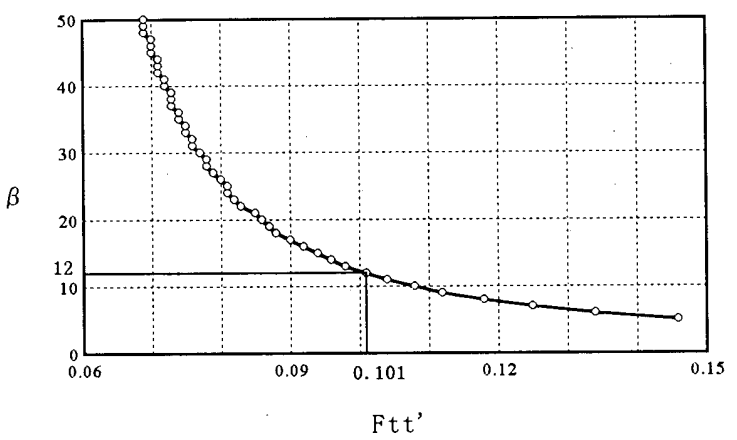

Fig $24 \beta$-Ftt' relation curve

\section{3 正モール・クーロンの破壤基策}

引張側を切断したモール・クーロンの破壊基準は、Fig 25 のよ うにあらわされ、压縮を正として $\sigma_{3}>\sigma_{1}$ のとき、破壊基準式およ び定数は

$$
\begin{aligned}
& \sigma_{3} \frac{1-\sin \phi}{2 \mathrm{C} \cos \phi}-\sigma_{1} \frac{1+\sin \phi}{2 \mathrm{C} \cos \phi}=1 \\
& \mathrm{~F}_{\mathrm{c}}=\frac{2 \mathrm{C} \cos \phi}{1-\sin \phi}
\end{aligned}
$$




$$
\begin{aligned}
& \mathrm{C}=\frac{\mathrm{Fc}}{2} \frac{1-\sin \phi}{\cos \phi}=\tau \mathrm{o} \\
& \sigma \mathrm{o}=\frac{\mathrm{C} \cos \phi-\mathrm{Ft}}{1-\sin \phi} \\
& \mathrm{r}=\sigma \mathrm{o}+\mathrm{Ft} .
\end{aligned}
$$

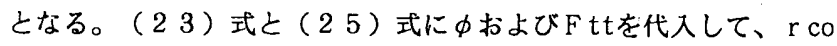
s $\phi$ C との比をとると、

$$
\frac{\mathrm{r} \cos \phi}{\mathrm{C}}=\frac{0.27352 \mathrm{Fc} \cos \phi}{0.15765 \mathrm{Fc}}=0.995
$$

\section{引張側の円弧は圧縮側の破壊基準直線}

$$
|\tau|=\tan \phi \cdot \sigma+C
$$

と、縌軸（ $\tau$ 軸）上でほぼ接していることになり、これはモール・ クーロンの基準が点 $(0, C) 、(0,-C) て ゙$ 直線（（2 6 ）に接する円弧で 切断されていることを示す。

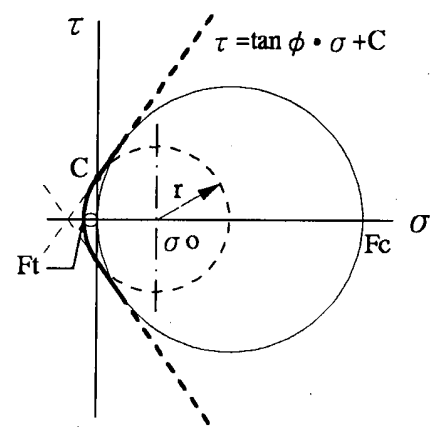

Fig 25 Mohr-Coulomb's modified failure envelope

\section{4. $4 \mathrm{R}$ C 柱の英鮯結果}

Fig 26 、Fig 27 は文献 7 の資料を基に R C 柱の実験結果をくさ び理論に適用した場合の実験值と理論値の比較を示したものである。 Fig 26 は、 $\phi=37^{\circ} 、 F t t=0.1$ とし、Fig 27 は $\phi=55^{\circ} 、$ $\mathrm{Ftt}=0.05$ として求めたものである。この結果から、実験值と理 論值の比の分布は、特に理論値による $\mathrm{Q} / \mathrm{B} \cdot \mathrm{D} \cdot \mathrm{F} \mathrm{c} \geqq 0.1$ の範囲 で、1．1〜0．7の範囲から $1.2 \sim 0.8$ の間に変化し、分布 状況が改善されたことが分かる。

\section{5. むすひ}

Plain concrete の圧裂試験の結果、 $\mathrm{F} \mathrm{c}=240 \sim 345 \mathrm{kgf} /$ $\mathrm{cm}^{2}$ (テストピースの压縮試験結果の分布範囲) の範囲で、コンクリ 一ト(モルタル) の内部摩摖角 対する比Fttは、 $\phi=55^{\circ} 、 \mathrm{Ftt}=0.05$ のときにくさび理論に よる解によく一致することが分かった。この結果は円柱の割裂試験 の引張強度の近似理論解とくさび理論解の等置により求められる内 部摩摖角 $\phi=57.5^{\circ}$ にほぼ一致する。

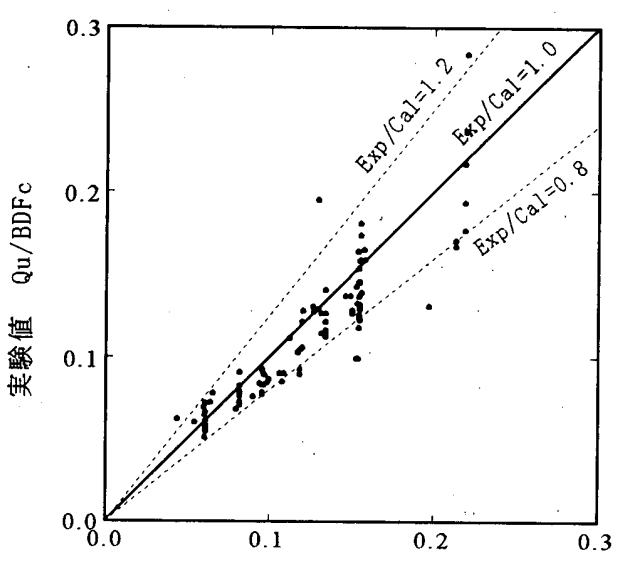

理論値 Qu/BDFc

Fig 26 RC柱の実験結果と理論値 $\phi=37^{\circ} 、 \mathrm{Ftt}=0.1$ の場合

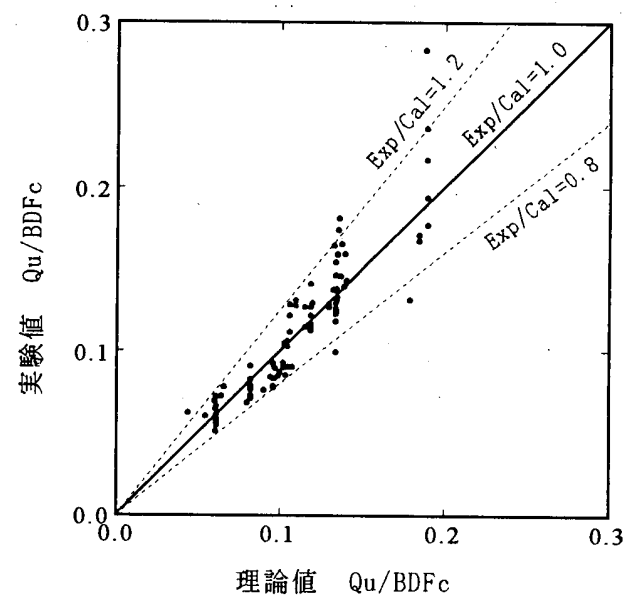

Fig 27 RC柱の実験結果と理論値 $\phi=55^{\circ} 、 \mathrm{Ftt}=0.05$ の場合

\section{6. 部辞}

本実験は日本大学生産工学部建築工学科、花井研究室において行 ったもので、卒論生諸兄の全面的なご協力を得ましたことを記して 謝意を表します。

\section{㚛考文部}

1) 末永保美、石丸嫾太郎：組み合わせ応力を受けるコンクリート材の動力学的 解析（その3）、日本建築学会論文報告集 第 220 号 $\mathrm{ppl} \sim 7 \quad 1974.4$

2) 末永保美、石丸麟太郎：組み合わせ応力を受けるコンクリート材の動力学的 解析（その 4)、日本建策学会論文報告集 第 221 号 $\mathrm{pp} 9 \sim 161974.7$

3) 浅川敏雄、石丸麟太郎、吉田宏、末永保美 : 高首壁式プレキャス卜铁筋コン クリート造のピロティに用いる鋼管巻きRC柱のせん断強度に関する研究、 日本建築学会構造系論文集 第4 60 号 pp143 152 1994.6

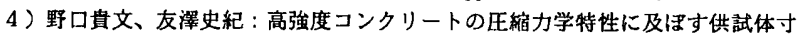
法・形状の影暗、日本貄学学会樓造系諭文集 第 473 号 pp19 28 1995. 7

5) コンクリート工学ハンドブック 朝倉書店 pp277、278 1972年

6) W. F. Chen : コンクリート構造物の塑性解析 pp84、320 丸善株式会社 1985. 7

7 ）広沢雅也：建筑研究資料 No2 既往の R C 柱実験登料 建設省建築研究所 1973 